\title{
PENGARUH KOMUNIKASI INTERPERSONAL PIMPINAN, MOTIVASI KERJA DAN LINGKUNGAN KERJA, TERHADAP KEPUASAN KERJA KARYAWAN DI HOTEL INTERCONTINENTAL MIDPLAZA JAKARTA
}

\author{
Wibowo Cahyoseputro $^{(1)}$, Lies T. Juliawati ${ }^{2)}$, dan Ersri Rokhaminawanti \\ 1,2,3 Manajemen, STIE STEMBI BANDUNG \\ 1,2,3 Jl. Buah Batu No. 26, Kota Bandung, 40262 \\ E-mail : dosenwibowo@gmail.com ${ }^{1)}$,dosenlieta@gmail.com ${ }^{2)}$, iersri3@gmail.com ${ }^{3)}$
}

\begin{abstract}
ABSTRAK
Pemimpin sebagai penggerak harus mempunyai kemampuan yang baik dalam organisasi, kemampuan tersebut memerlukan proses pengembangan yang dinamis untuk terus menerus dikaji sesuai kebutuhan sepanjang waktu. Tujuan dilakukan penelitian untuk menganalisa pengaruh komunikasi interpersonal pimpinan, motivasi kerja, lingkungan kerja serta kepuasan kerja karyawan. Hasil penelitian tentang komunikasi interpersonal pimpinan di perusahaan tersebut kurang efektif, hal tersebut dapat dilihat dari hasil pengumpulan data yang diterima dari responden. Sedangkan motivasi kerja karyawan berdasarkan jawaban responden tentang butir pertanyaan motivasi kerja karyawan, bahwa motivasi yang dilakukan oleh pimpinan terhadap karyawan kurang mendorong dalam bekerja. Akan tetapi motivasi kerja tidak berpengaruh signifikan terhadap kepuasan kerja karyawan. Berdasarkan jawaban responden tentang butir pertanyaan lingkungan kerja bahwa responden yang menjawab dan menganggap bahwa lingkungan kerja tidak nyaman dan kurang nyaman hasilnya menyatakan lingkungan kerja berpengaruh signifikan terhadap kepuasan kerja di lingkungan.
\end{abstract}

Kata Kunci: Pengaruh Komunikasi Interpersonal, Pimpinan, Motivasi Kerja, Lingkungan Kerja, Kepuasan Kerja

\section{PENDAHULUAN}

Pengembangan dunia pariwisata harus dilandasi dengan perencanaan yang matang secara menyeluruh, antara yang satu dengan lainnya harus terpadu dalam satu jalinan yang teguh dan kompak, sehingga masyarakat luas dapat memanfaatkannya dengan baik. Pembangunan dan pengembangan pariwisata di Indonesia merupakan tanggung jawab bersama antara pemerintah dengan pengusaha dalam memberikan jaminan keamanan dan kenyamanan sebagai salah satu strategi dalam meningkatkan sumber devisa dari pariwisata.

Majunya industri pariwisata suatu daerah sangat bergantung kepada jumlah wisatawan yang datang, Consumers are looking for new and unusual places to explore and different activities to undertake, Konsumen mencari tempat baru dan tidak biasa untuk dijelajahi dan berbagai kegiatan untuk dilakukan, hal tersebut harus ditunjang dengan peningkatan pemanfaatan Daerah Tujuan Wisata (Scott dalam Khan, 2017). Wisatawan yang datang ke daerah tujuan wisata memerlukan akomodasi yang salah satunya adalah hotel yang digunakan untuk menginap. Industri Perhotelan merupakan industri jasa yang bersifat "labour-intensive", dan "people based industry" artinya banyak sekali melibatkan tenaga kerja yang kompeten dan profesional, dan karyawan merupakan aset utama. Understanding that there is tourism demand for experiences, tourismmarketing professionals have begun to offer products and services that offer some type of experience, adanya pemahaman tentang kebutuhan pariwisata yang membutuhkan pengalaman yang profesional dari staff pemasaran pariwisata yang dimulai dengan menawarkan produk dan pelayanan yang menawarkan beberapa pengalaman (Lohmann dan Netto, 2017). Pelayanan yang dilakukan oleh para staff merupakan bagian penting yang dibutuhkan dalam industri pariwisata khususnya dalam bidang perhotelan. Para pelanggan yang berkunjung akan merasakan kenyamanan saat mereka diperlakukan dengan penuh hormat oleh seluruh staff.

Hotel InterContinental Midplaza Jakarta , sebagai hotel yang berada di Jakarta yang merupakan pusat ekonomi Indonesia. Beragam jenis kegiatan perdagangan dan industri dilakukan dan membutuhkan sarana akomodasi yang mampu memenuhi kegiatan tersebut. Untuk memenuhi kepuasan tamu diperlukan karyawan yang mampu memberikan pelayanan yang terbaik.

Sebagaimana diketahui bahwa kunci keberhasilan industri hotel ditentukan oleh kepuasan para tamu dan kepuasan para tamu sebagian besar ditentukan oleh pelayanan dan keramahtamahan yang diberikan oleh seluruh karyawan hotel dari pucuk pimpinan sampai dengan para petugas di lapangan. Hotel sebagai salah satu usaha yang bergerak di bidang jasa memiliki keharusan untuk menjamin kualitas layanan secara terusmenerus yang secara langsung maupun tidak langsung berdampak kepada konsumen. Satu-satunya faktor yang menunjukkan keunggulan kompetitif dalam bisnis global adalah potensi sumber daya manusia (SDM) yang berkualitas (Edison, 2018). Industri perhotelan 
merupakan industri jasa yang memadukan antara produk dan layanan. Permasalahan yang dihadapi oleh Hotel InterContinental Midplaza Jakarta adalah masalah penanganan yang berhubungan dengan kebutuhan konsumen. Karyawan yang berhadapan langsung maupun tidak langsung dengan konsumen memiliki tugas dan tanggung jawab yang besar untuk tetap menjaga kualitas layanan sehingga dapat mencegah ketidakpuasan konsumen.

Pemimpin sebagai penggerak harus mempunyai kemampuan komunikasi interpersonal yang baik dalam organisasi, kemampuan tersebut memerlukan proses pengembangan yang dinamis untuk terus menerus dikaji sesuai kebutuhan sepanjang waktu. Komunikasi interpersonal pimpinan sangat dibutuhkan agar karyawan merasa dapat mengembangkan diri dengan dukungan pimpinan, terkadang karyawan merasa muncul hambatan dalam komunikasi, karyawan berharap komunikasi antara atasan dan bawahan bisa terjadi setiap saat. Komunikasi interpersonal merupakan komunikasi yang paling ampuh dalam memersuasi orang untuk mengubah sikap, opini, perilaku komunikan dan jika dilakukan secara tatap muka langsung akan lebih intensif

Beberapa perilaku kerja karyawan mempengaruhi hasil kerja yang berhubungan dengan tingkat kepuasan tamu, pengembangan sumber daya manusia dapat dilaksanakan dengan baik, harus di tetapkan program pengembangan sumber daya manusia (Sedarmanyati, 2017). Program pengembangan sumber daya manusia perlu disusun secara cermat, dan didasarkan metode ilmiah serta berpedoman keterampilan yang dibutuhkan perusahaan saat ini dan untuk masa yang akan datang. Kepuasan kerja memiliki efek negatif pada intention turnover karyawan (Ibrahim, 2017). Hasil analisis regresi mengungkapkan bahwa ada hubungan negatif yang signifikan antara kepuasan kerja dan intention turnover karyawan. Sedangkan dari pengamatan sementara dan wawancara, penurunan hasil kerja yang terjadi oleh karyawan didasarkan oleh tingkat kepuasan karyawan dalam bekerja. Berdasarkan hasil dari pengamatan juga, timbul berbagai sikap negatif dari karyawan yang sedikit banyak mempengaruhi terciptanya visi, misi, tujuan, sasaran atau target perusahaan secara efektif dan efisien. Beberapa hal yang menunjukkan bahwa kepuasan sebagian karyawan belum dapat dipenuhi, berdampak kepada beberapa karyawan yang merasa tidak merekomendasikan hotel ini sebagai tempat yang bagus untuk bekerja, sebagian karyawan merasa tidak ingin melakukan usaha lebih dalam bekerja, sebagian karyawan merasa tindakan dari tim manajemen yang kurang konsisten.

Pada dasarnya kepuasan kerja merupakan hal yang bersifat individual karena setiap individu akan memiliki tingkat kepuasan yang berbeda-beda sesuai dengan nilainilai yang berlaku dalam diri setiap individu. $d$ Untuk bertahan dalam lingkungan bisnis yang dinamis, organisasi harus mengadopsi praktik manajemen sumber daya manusia berbasis kompetensi, yang diperlukan untuk produktivitas dan keunggulan kinerja. Karyawan lebih peduli tentang kemajuan mereka dalam karir mereka. Semakin banyak aspek dalam pekerjaan yang sesuai dengan keinginan individu, maka semakin tinggi tingkat kepuasan yang dirasakan. Hal lain yang di dapatkan dari pengamatan dan wawancara adanya perasaan jenuh dan bosan dari karyawan.

Penilaian kinerja semakin menjadi bagian dari pendekatan strategis untuk di integrasikan di Kegiatan SDM dan kebijakan bisnis. Penilaian kinerja mengacu pada semua prosedur yang digunakan untuk mengevaluasi kepribadian (Singh, 2016). Kurangnya motivasi, yang berdampak pada sebagian karyawan yang telah bekerja lebih dari lima tahun, mereka merasa jenuh dalam melakukan pekerjaan. Pemberdayaan sumber daya manusia (SDM) berpengaruh positif dan signifikan terhadap motivasi kerja, perubahan organisasi, dan kinerja organisasi usaha, dan motivasi kerja berpengaruh positif dan signifikan terhadap perubahan organisasi, dan kinerja organisasi. Sedangkan perubahan organisasi berpengaruh positif dan signifikan terhadap kinerja organisasi usaha perhotelan. sebagian karyawan merasa bahwa mereka kurang bisa berkembang dalam karier mereka, sebagian karyawan kurang diberikan kepercayaan dalam melaksanakan pekerjaannya, sebagian karyawan merasa kurangnya kepedulian dari pihak manajemen. Pekerjaan yang dihadapi dari waktu ke waktu, jam ke jam, menit ke menit dan relatif membosankan membuat motivasi kerja menurun, karena karyawan merasa bahwa apa yang dikerjakan tidak mengandung sesuatu yang baru. Karyawan seolah-olah sudah mempunyai rekaman terhadap apa saja yang harus dikerjakan, dan fungsi karyawan lebih banyak seperti menjadi robot. Akibatnya, kondisi seperti itu lambat laun akan mendatangkan kebosanan pada diri karyawan dalam melakukan pekerjaan ( Sutawa , 2015).

Lingkungan kerja memiliki hubungan negative dan signifikan terhadap stres kerja pegawai. Koefisien korelasi menunjukkan bahwa peningkatan lingkungan kerja pegawai ke arah yang kondusif berhubungan dengan penurunan tingkat stres kerja pegawai artinya semakin kondusif lingkungan kerja maka stres pegawai dapat meminimalisasikan. Hasil dari pengamatan dan wawancara, sebagian karyawan merasa bahwa suasana lingkungan kerja kurang ergonomis yang mengakibatkan pelayanan banyak terhambat, sebagian karyawan merasa bahwa beberapa peralatan pendukung pekerjaan kurang dapat digunakan maksimal karena sudah tidak berfungsi dengan baik yang berdampak kepada efisiensi dalam bekerja (Luma (2017). Karyawan yang bahagia menyebabkan karyawan lebih produktif. Bagi perusahaan, kepuasan kerja karyawan dapat bermanfaat karena karyawan yang puas terhadap pekerjaannya dapat meningkatkan produktivitas, perbaikan sikap, dan tingkah laku (Robbins, 2015).

Berdasarkan beberapa kajian penelitian terdahulu penelitian ini merupakan pengembangan penelitian terdahulu. Sedangkan State of the Art penelitian ini 
adalah, belum ada penelitian yang meneliti tentang pengaruh komunikasi interpersonal pimpinan, motivasi kerja dan lingkungan kerja terhadap kepuasan kerja karyawan di lingkungan hotel. Penulis belum menemukan penelitian dengan tiga variabel yang digunakan untuk menganalisa kepuasan karyawan di hotel. Dengan digunakan tiga variabel tersebut agar dapat digunakan sebagai evaluasi dalam upaya meningkatkan kepuasan karyawan. Maka jelas terlihat bahwa pilihan penulis untuk melakukan penelitian adalah novelty bagi penulis.

\section{RUANG LINGKUP}

Dalam penelitian ini permasalahan berdasarkan gambaran pada pendahuluan diatas, maka disusun rumusan masalah sebagai berikut:

1. Seberapa besar pengaruh komunikasi interpersonal pimpinan (X1) terhadap kepuasan kerja karyawan (Y) pada Hotel InterContinental Midplaza Jakarta

2. Seberapa besar pengaruh motivasi kerja (X2) terhadap kepuasan kerja karyawan (Y) pada Hotel InterContinental Midplaza Jakarta

3. Seberapa besar pengaruh lingkungan kerja (X3) terhadap kepuasan kerja karyawan (Y) pada Hotel InterContinental Midplaza Jakarta

4. Seberapa besar pengaruh komunikasi interpersonal pimpinan (X1), moivasi kerja (X2), lingkungan kerja (X3) secara bersama-sama terhadap kepuasan kerja karyawan (Y) pada Hotel InterContinental Midplaza Jakarta

\section{BAHAN DAN METODE}

Diperlukan landasan kerangka teoritis dan kerangka berpikir konseptual dalam penulisan serta pengumpulan data yang berisikan populasi, sampel, teknik pengujian, teknik pengolahan dan analisis data.

\subsection{Bahan Penelitian}

Definisi variabel komunikasi interpersonal pimpinan (Joseph A. Devito, 2015) yaitu:

1. Keterbukaan (openness)

Kemauan menanggapi dengan senang hati informasi yang diterima di dalam menghadapi hubungan antar pribadi. Kualitas keterbukaan mengacu pada tiga aspek dari komunikasi interpersonal. Pertama, komunikator interpersonal yang efektif harus terbuka kepada komunikannya. Ini tidaklah berarti bahwa orang harus dengan segera membukakan semua riwayat hidupnya. Memang ini mungkin menarik, tetapi biasanya tidak membantu komunikasi. Sebaliknya, harus ada kesediaan untuk membuka diri mengungkapkan informasi yang biasanya disembunyikan, asalkan pengungkapan diri ini patut dan wajar. Aspek kedua mengacu pada kesediaan komunikator untuk bereaksi secara jujur terhadap stimulus yang datang. Orang yang diam, tidak kritis, dan tidak tanggap pada umumnya merupakan komunikan yang menjemukan. Bila ingin komunikan bereaksi terhadap apa yang komunikator ucapkan, komunikator dapat memperlihatkan keterbukaan dengan cara bereaksi secara spontan terhadap orang lain.

2. Empati (empathy)

kemampuan seseorang untuk mengetahui apa yang sedang dialami orang lain pada suatu saat tertentu, dari sudut pandang orang lain itu, melalui kacamata orang lain itu. Berbeda dengan simpati yang artinya adalah merasakan bagi orang lain. Orang yang berempati mampu memahami motivasi dan pengalaman orang lain, perasaan dan sikap mereka, serta harapan dan keinginan mereka untuk masa mendatang sehingga dapat mengomunikasikan empati, baik secara verbal maupun non-verbal.

3. Dukungan (supportiveness)

Situasi yang terbuka untuk mendukung komunikasi berlangsung efektif. Hubungan interpersonal yang efektif adalah hubungan dimana terdapat sikap mendukung. Individu memperlihatkan sikap mendukung dengan bersikap deskriptif bukan evaluatif, spontan bukan strategi.

4. Rasa Positif (costiveness)

Seseorang harus memiliki perasaan positif terhadap dirinya, mendorong orang lain lebih aktif berpartisipasi, dan menciptakan situasi komunikasi kondusif untuk interaksi yang efektif.

5. Kesetaraan (equality)

Komunikasi antarpribadi akan lebih efektif bila suasananya setara. Artinya, ada pengakuan secara diam-diam bahwa kedua belah pihak menghargai, berguna, dan mempunyai sesuatu yang penting untuk disumbangkan. Kesetaraan meminta kita untuk memberikan penghargaan positif tak bersyarat kepada individu lain.

Sedangkan definisi variable motivasi (Abraham Maslow dalam Mangkunegara, 2017) membagi kebutuhan manusia dalam lima tingkat, yaitu:

1. Kebutuhan fisiologis, yaitu kebutuhan untuk makan, minum, perlindungan fisik, bernafas, seksual. Kebutuhan ini merupakan kebutuhan tingkat terendah atau disebut juga sebagai kebutuhan yang paling besar.

2. Kebutuhan rasa aman, yaitu kebutuhan akan perlindungan dari ancaman, bahaya, pertentangan, dan lingkungan hidup.

3. Kebutuhan untuk merasa memiliki, yaitu kebutuhan untuk diterima oleh kelompok, berafiliasi, berinteraksi, dan kebutuhan untuk mencintai dan dicintai.

4. Kebutuhan akan harga diri, yaitu kebutuhan untuk dihormati, dan dihargai oleh orang lain.

5. Kebutuhan untuk mengaktualisasikan diri, yaitu kebutuhan untuk menggunakan kemampuan, skill, dan potensi. Kebutuhan untuk berpendapat dengan 
mengemukakan ide-ide memberi penilaian dan kritik terhadap sesuatu.

Sedangkan definisi variabel kepuasan kerja, Secara umum teori mengenai kepuasan kerja dibagi menjadi dua. Dua teori tersebut adalah, Teori Dua Faktor (Two-Factor Theory), dalam teori ini menunjukkan bahwa kepuasan dan ketidakpuasan berasal dari kelompok variabel yang berbeda. Variabel tersebut adalah, Satisfies/ motivator. Faktor ini merupakan situasi dimana kebutuhan untuk kepuasan kerja terdiri dari pekerjaan yang menarik dan penuh dengan tantangan, adanya kesempatan untuk berprestasi dan adanya kesempatan untuk mendapatkan penghargaan serta promosi (Priansa, 2017). Jika faktor tersebut terpenuhi maka akan menciptakan kepuasan kerja, tetapi jika faktor tersebut tidak terpenuhi maka belum tentu akan menciptakan ketidakpuasan. Sedangkan, Dissatisfies (Hygiene Factors) Dissatisfies (hygiene factors) merupakan kumpulan faktor-faktor yang menyebabkan timbulnya ketidakpuasan. Faktor-faktor tersebut antara lain kualitas dari pengawasan, lingkungan kerja, pembayaran gaji, keamanan, kualitas organisasi, hubungan kerja, serta kebijakan perusahaan.

Kepuasan kerja merupakan suatu cara pandang seseorang, baik yang bersifat positif maupun bersifat negatif tentang pekerjaannya. Banyak faktor yang perlu mendapat perhatian dalam menganalisis kepuasan kerja seseorang (Siagian, 2015).

Kepuasan kerja adalah suatu sikap karyawan terhadap pekerjaan yang berhubungan dengan situasi kerja, kerja sama antar karyawan, imbalan yang diterima dalam kerja, dan hal-hal yang menyangkut faktor fisik dan psikologis (Sutrisno, 2017).

Dimensi yang biasa digunakan untuk mengukur kepuasan kerja seorang karyawan menurut Robbins diterjemahkan oleh Wibowo (2017), adalah pekerjaan itu sendiri (work itself), gaji/upah, yaitu merupakan faktor multidimensi dalam kepuasan kerja, supervisi, yaitu kemampuan pimpinan untuk memberikan bantuan teknis dan dukungan perilaku, rekan kerja, yaitu hubungan antara rekan kerja yang kooperatif merupakan sumber kepuasan kerja yang paling sederhana.

Definisi variabel lingkungan kerja) Secara garis besar, jenis lingkungan kerja terbagi menjadi lingkungan kerja fisik, dan lingkungan kerja non fisik, lingkungan kerja fisik adalah semua yang terdapat di sekitar tempat kerja yang dapat mempengaruhi pegawai baik secara langsung maupun tidak langsung (Sedarmayanti (2015).

Lingkungan kerja sebagai sumber informasi dan tempat untuk melakukan aktivitas, sehingga kondisi lingkungan kerja yang baik harus diwujudkan agar karyawan merasa lebih betah dan nyaman di dalam ruang kerja untuk menyelesaikan pekerjaannya, sehingga tingkat efisiensi yang tinggi dapat tercapai (Nitisemito, 2014).

\subsection{Metode Penelitian}

Penelitian survei adalah penelitian yang dilakukan pada populasi besar maupun kecil, tetapi data yang dipelajari adalah data dari sampel yang diambil dari populasi tersebut, sehingga ditemukan kejadian-kejadian relatif, distribusi, dan hubungan antar variabel sosiologis maupun psikologis. Dalam penelitian kuantitatif, penggunaan survei merupakan salah satu jenis metode penelitian deskriptif yang dilakukan pada populasi besar maupun kecil terhadap fenomena yang berkenaan dengan berbagai aspek populasi tersebut untuk memperoleh informasi yang aktual. Cara utama dalam pengumpulan informasi adalah dengan mengajukan pertanyaan kepada responden yang jawabannya kemudian merupakan daya yang akan dianalisis.

Teknik utama yang digunakan dalam pengumpulan data survei adalah bertanya. Penelitian survei ini serbaguna dan cukup efisien digunakan dalam penelitian. Namun penelitian survei ini sangat bergantung kepada kemampuan dan kemauan responden untuk bekerja sama. Pada gambar 1 dapat dilihat alur kerja penelitian

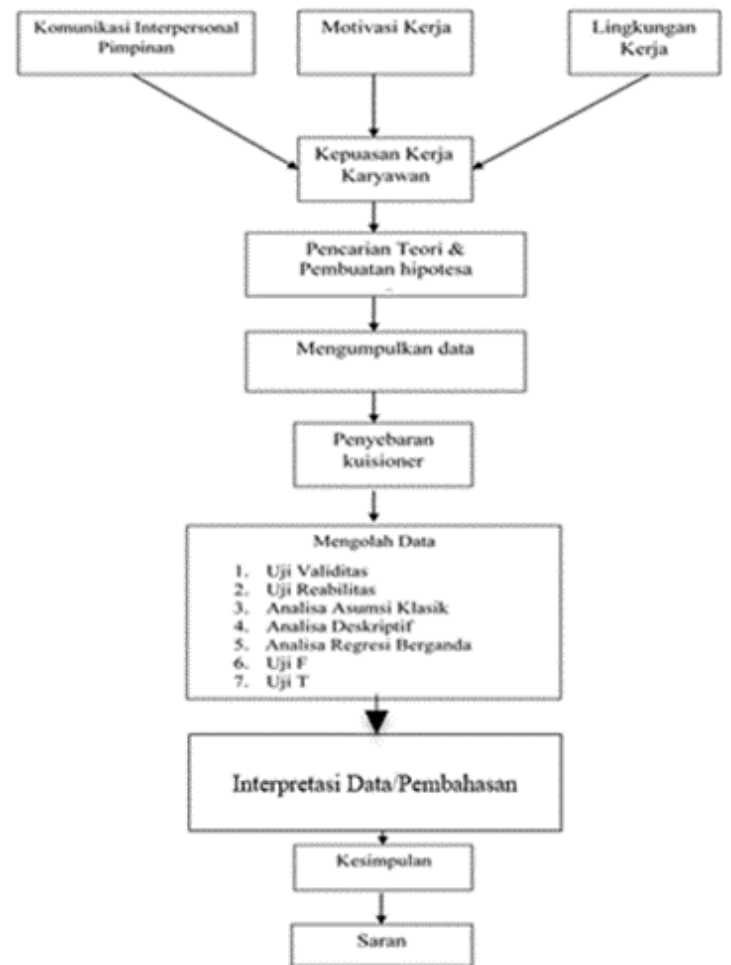

Gambar 1. Alur Kerja Penelitian

\section{PEMBAHASAN}

Menampilkan aplikasi yang dibangun, baik dalam bentuk software, hardware, jaringan komputer, dan lainlain. Sertakan data pendukung yang berupa desain/perancangan, tabel, grafik, gambar, atau alat penolong lain seperlunya untuk memperjelas dan mempersingkat uraian yang harus diberikan.

Kerangka pemikiran dalam penelitian adalah komunikasi interpersonal pimpinan, motivasi kerja dan lingkungan kerja mempunyai pengaruh terhadap 
kepuasan kerja karyawan dapat dilihat pada gambar 2 berikut ini:

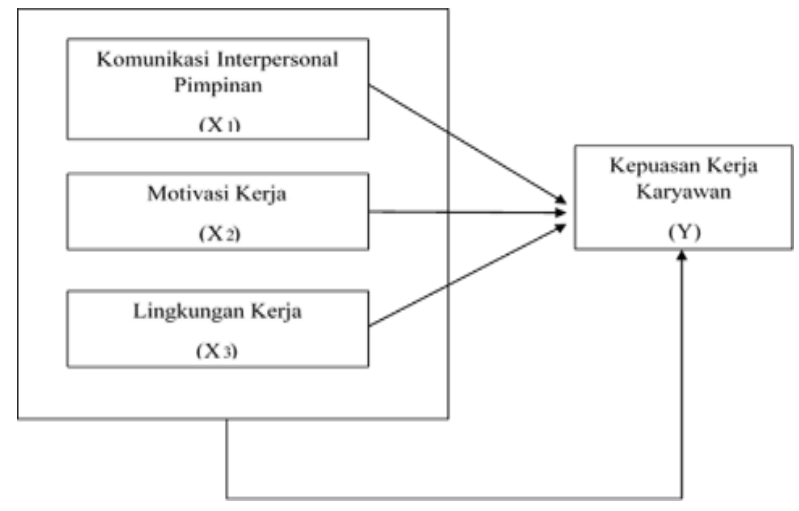

Gambar 2. Kerangka pemikiran

Hipotesis adalah jawaban teoritis terhadap rumusan masalah penelitian;

1. Terdapat pengaruh yang signifikan secara parsial variabel komunikasi interpersonal pimpinan $\left(\mathrm{X}_{1}\right)$ terhadap variabel kepuasan kerja karyawan (Y).

2. Diduga terdapat pengaruh yang signifikan secara parsial variabel motivasi kerja $\left(\mathrm{X}_{2}\right)$ terhadap variabel kepuasan kerja karyawan (Y).

3. Diduga terdapat pengaruh yang signifikan secara parsial variabel lingkungan kerja $\left(\mathrm{X}_{3}\right)$ terhadap variabel kepuasan kerja karyawan (Y).

4. Diduga terdapat pengaruh secara simultan variabel komunikasi interpersonal pimpinan $\left(\mathrm{X}_{1}\right)$, motivasi kerja $\left(\mathrm{X}_{2}\right)$ dan lingkungan kerja $\left(\mathrm{X}_{3}\right)$ terhadap variabel kepuasan kerja karyawan (Y).

Sedangkan berdasarkan hipotesis kerja sebagai berikut:

1. $\mathrm{H}_{0}$ : Komunikasi Interpersonal Pimpinan tidak berpengaruh secara positif terhadap kepuasan karyawan

2. $\mathrm{H}_{1}$ : Komunikasi Interpersonal Pimpinan berpengaruh secara positif terhadap kepuasan karyawan

3. $\mathrm{H}_{0}$ : Motivasi tidak berpengaruh secara positif terhadap kepuasan karyawan

4. $\mathrm{H}_{1}$ : Motivasi berpengaruh secara positif terhadap kepuasan karyawan

5. $\mathrm{H}_{0}$ : Lingkungan kerja tidak berpengaruh secara positif terhadap Kepuasan karyawan

6. $\mathrm{H}_{1}$ : Lingkungan kerja berpengaruh secara positif terhadap Kepuasan karyawan

7. $\mathrm{H}_{0}$ : Komunikasi Interpersonal Pimpinan, motivasi dan lingkungan kerja secara bersama-sama tidak berpengaruh secara positif terhadap kepuasan karyawan.

8. $\mathrm{H}_{1}$ : Komunikasi Interpersonal Pimpinan, motivasi dan lingkungan kerja secara bersama-sama berpengaruh secara positif terhadap kepuasan karyawan

\subsection{Hasil Uji Validitas}

Untuk semua angket kuesioner Variabel Komunikasi Interpersonal Pimpinan (X1) dinyatakan valid, Motivasi Kerja (X2) dinyatakan valid, Lingkungan Kerja (X3) dinyatakan valid dan Kepuasan Kerja (Y) dinyatakan valid setelah dibandingkan dengan nilai rtabel = 0,361.Uji Validitas digunakan untuk mengetahui valid nya angket dalam mengumpulkan data. Uji validitas dilaksanakan dengan rumus korelasi bivariate person dengan alat bantu program SPSS versi 22 .

\subsection{Hasil Uji Reliabilitas}

Berdasarkan nilai koefisien reliabilitas tersebut dapat disimpulkan bahwa semua angket yang digunakan dalam penelitian ini reliabel atau konsisten, sehingga dapat digunakan sebagai instrument dalam penelitian.

Hasil uji reliabilitas diperoleh nilai koefisien reliabilitas angket $\mathrm{X} 1$ sebesar 0,751 , angket $\mathrm{X} 2$ sebesar 0,766, angket X3 sebesar 0,764 dan angket $\mathrm{Y}$ sebesar 0,765

\subsection{Uji Asumsi Klasik}

Sebelum melakukan pengujian hipotesis, terlebih dahulu dilakukan pengujian terjadinya penyimpangan terhadap asumsi klasik, beberapa pengujian yang harus dilakukan adalah:

\subsubsection{Hasil Uji Normalitas}

Hasil uji ini menghasilkan variabel residu distribusi normal, dari grafik Histogram dapat diketahui bahwa grafik membentuk gunung atau lonceng, sehingga dapat disimpulkan bahwa model regresi memenuhi asumsi normalitas Sebagaimana diketahui bahwa kunci keberhasilan industri hotel ditentukan oleh kepuasan para tamu dan kepuasan para tamu sebagian besar ditentukan oleh pelayanan dan keramahtamahan yang diberikan oleh seluruh karyawan hotel dari pucuk pimpinan sampai dengan para petugas di lapangan.

Pada gambar 3 data terdistribusi normal dan menunjukkan keseimbangan penyebaran data di sebelah kiri dan kanan dari Histogram, 


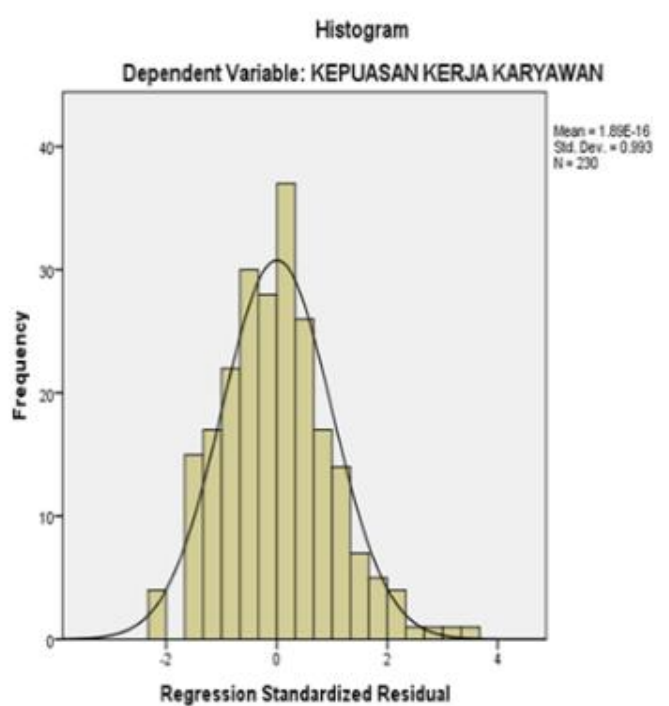

Gambar 3. Histogram Kepuasan Kerja Karyawan

Berdasarkan gambar 4 grafik Normal P-P Plot diketahui bahwa titik menyebar sekitar garis mengikuti garis diagonal. Dengan ini maka data residual terdistribusi secara normal, sehingga dapat disimpulkan bahwa model regresi memenuhi asumsi normalitas.

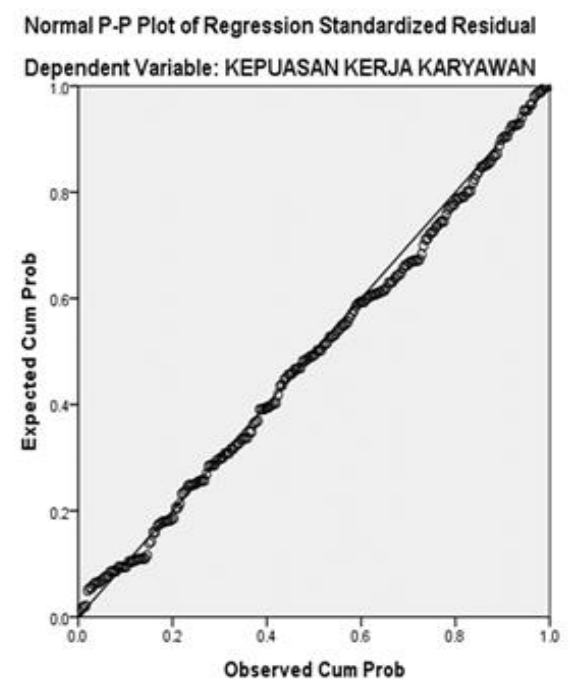

Gambar 4 P-P Plot Kepuasan Kerja Karyawan

\subsubsection{Hasil Uji Multikolineritas}

Hasil uji ini dapat disimpulkan data tidak terjadi multikolineritas. Uji ini dilakukan bertujuan untuk menguji apakah dalam model regresi ditemukan adanya korelasi antar variabel bebas. Model regresi yang baik seharusnya tidak terjadi korelasi diantara variabel bebas, dan hasil diperoleh nilai toleransi lebih besar 0,01 dengan nilai VIF lebih kecil 10,

\subsubsection{Uji Heteroskedasitas}

Hasil uji ini dapat disimpulkan bahwa pada model regresi tidak ada masalah heteroskedasitas. Uji ini untuk menguji apakah dalam model regresi terjadi ketidaksamaan variance dari residual satu pengamatan ke pengamatan yang lain. Jika variance dari absolute residual satu pengamatan ke pengamatan lain tetap, maka disebut homoskedasitas dan jika berbeda disebut heteroskedesitas. Maka diperoleh nilai signifikansi uji t ketiga variabel independen dengan Absolut Residual (ABS_RES) lebih dari 0,05.

\subsection{Analisis Deskripsi}

Berdasarkan hasil pengumpulan data di lapangan, melalui pengumpulan jawaban yang diperoleh dari responden, maka diperoleh gambaran mengenai kondisi objek penelitian.

Data Variabel adalah menampilkan gambaran umum mengenai jawaban responden atas pertanyaan atau pernyataan yang terdapat dalam kuesioner (tertutup) maupun tanggapan responden (terbuka).

1. Deskripsi Variabel Komunikasi Interpersonal Pimpinan

Sebanyak 52,55 \% responden menganggap bahwa komunikasi interpersonal pimpinan kurang efektif dan tidak efektif sebanyak 38,49. 3 variabel pertanyaan tersebut yang mendapat nilai terbesar yang menganggap komunikasi interpersonal pimpinan kurang efektif dan tidak efektif : kuesioner pimpinan saya memberikan kesempatan dan memahami pandangan dari sudut saya. Saya diberikan kesempatan untuk berinteraksi dengan atasan. Dan pimpinan saya mendukung saya menyelesaikan masalah dengan baik.

2. Deskripsi Variabel Motivasi Kerja

Sebanyak 51,52 \%, menganggap bahwa motivasi kerja kurang mendorong dan tidak mendorong sebanyak 41,47 \%. 3 variabel pertanyaan tersebut yang mendapat nilai terbesar yang menganggap motivasi kerja kurang mendorong dan tidak mendorong : kuesioner saya diberikan arahan dalam bekerja, saya diberikan arahan berkarier lebih tinggi dan saya diberikan arahan untuk meningkatkan keterampilan dan pengetahuan.

3. Deskripsi Variabel Lingkungan Kerja

Sebanyak 49,17\%, menganggap bahwa lingkungan Kerja tidak nyaman dan kurang nyaman sebanyak 47,55 \%. 3 variabel pertanyaan tersebut yang mendapat nilai terbesar yang menganggap Lingkungan kerja tidak nyaman dan kurang nyaman : kuesioner musik yang lembut di ruangan membuat saya merasa nyaman dalam bekerja, keamanan ditempat kerja saya membuat saya merasa aman dalam bekerja dan rekan kerja saya saling mendukung dalam melaksanakan tugas.

4. Deskripsi Variabel Kepuasan Kerja Karyawan Sebanyak 53,06 \%, menganggap Kurang puas dan Tidak puas sebanyak 37,30 \%. 3 variabel pertanyaan tersebut yang mendapat nilai terbesar yang menganggap kepuasan kerja karyawan kurang puas 
dan tidak puas: kuesioner gaji yang saya terima sesuai dengan beban kerja, gaji yang saya terima membuat saya puas, gaji yang saya terima mampu memenuhi kebutuhan hidup saya dan keluarga saya.

\subsection{Pengujian Hipotesis}

Sebelum melakukan pengujian hipotesis, terlebih dahulu dilakukan pengujian terjadinya penyimpangan terhadap asumsi klasik, beberapa pengujian yang harus dilakukan.

\subsubsection{Hasil Analisis Pengaruh Parsial Dengan Uji t}

Terdapat 3 hipotesis (Ha) yang diajukan dalam uji t tersebut: Tingkat kepercayaan yang digunakan adalah 95 $\%$, maka nilai $\alpha=0,05$. Dasar yang digunakan dalam pengambilan keputusan dalam uji t pertama,

1. H0 diterima dan $\mathrm{H} 1$ ditolak jika nilai $t_{\text {hitung }}<\mathrm{t}$ tabel atau jika nilai $\mathrm{Sig}>0,05$

2. H0 ditolak dan H1 diterima jika nilai $t_{\text {hitung }}>t$ tabel atau jika nilai $\mathrm{Sig}<0,05$

Sedangkan rumus untuk mencari $\mathrm{t}$ tabel dalam bentuk rumus :

1. $\mathrm{t}_{\text {tabel }}=(\alpha / 2: \mathrm{n}-\mathrm{k}-1)$

2. $\mathrm{t}_{\text {tabel }}=(0,05 / 2: 230-3-1)$

3. $\mathrm{t}_{\text {tabel }}=(0,025: 226)$

4. $\mathrm{t}_{\text {tabel }}=$ angka $0,025,226$ pada nilai distribusi $\mathrm{t}_{\text {tabel }}$ maka didapatkan nilai $t_{\text {tabel }}$ sebesar 1,970

Berdasarkan hasil Uji $\mathrm{t}$ pada keempat variabel tersebut, uji t pertama untuk mengetahui apakah variabel komunikasi interpersonal pimpinan (X1) berpengaruh signifikan terhadap kepuasan kerja karyawan (Y).

Berdasarkan nilai koefisien regresi variabel komunikasi interpersonal pimpinan (X1) adalah sebesar 0,005 bernilai positif , bahwa dikatakan Komunikasi interpersonal pimpinan (X1) berpengaruh positif terhadap kepuasan kerja karyawan (Y), semakin meningkatkan Komunikasi Interpersonal Pimpinan (X1) maka akan meningkatkan kepuasan kerja karyawan (Y). Hipotesis (Dugaan) dalam uji t pertama adalah:

1. $\mathrm{H}_{0}=$ Komunikasi Interpersonal Pimpinan (X1) tidak berpengaruh signifikan terhadap Kepuasan Kerja Karyawan (Y)

2. $\mathrm{H}_{1}=$ Komunikasi Interpersonal Pimpinan (X1) berpengaruh signifikan terhadap Kepuasan Kerja Karyawan (Y).

Hasil dan pengambilan keputusan dalam uji t: Diperoleh nilai $t_{\text {hitung }}$ sebesar $0,005<t_{\text {tabel }} 1,970$. Nilai (Sig) 0,996 > 0,05. Maka disimpulkan bahwa $\mathrm{H}_{0}$ diterima dan $\mathrm{H}_{1}$ ditolak, yang berarti Komunikasi interpersonal Pimpinan (X1) tidak berpengaruh signifikan terhadap (Y).

Uji t kedua untuk mengetahui apakah variabel motivasi kerja (X2) berpengaruh signifikan terhadap kepuasan kerja karyawan (Y). Berdasarkan nilai koefisien regresi variabel Motivasi Kerja (X2) adalah sebesar 0,392 bernilai +, bahwa dikatakan Motivasi Kerja (X2) berpengaruh positif terhadap kepuasan kerja karyawan (Y), semakin meningkatkan Motivasi Kerja
(X2) maka akan meningkatkan kepuasan kerja karyawan (Y). Hipotesis (dugaan) dalam uji t pertama adalah

1. $\mathrm{H}_{0}=$ Motivasi Kerja (X2) tidak berpengaruh signifikan terhadap Kepuasan Kerja Karyawan (Y)

2. $\mathrm{H}_{1}=$ Motivasi Kerja (X2) berpengaruh signifikan terhadap Kepuasan Kerja Karyawan (Y)

Hasil dan pengambilan keputusan dalam uji t kedua: Diperoleh nilai $t_{\text {hitung }}$ sebesar $1,964<t_{\text {tabel }} 1,970$ Nilai (Sig) 0,051 >0,05. Maka disimpulkan bahwa $\mathrm{H}_{0}$ diterima dan $\mathrm{H}_{1}$ ditolak, yang berarti motivasi kerja (X2) tidak berpengaruh signifikan terhadap (Y).

Uji t ketiga untuk mengetahui apakah variabel Lingkungan Kerja (X3) berpengaruh signifikan terhadap kepuasan kerja karyawan(Y). Berdasarkan nilai koefisien regresi variabel lingkungan kerja (X3) adalah sebesar 0,277 bernilai positif + , bahwa dikatakan lingkungan kerja (X3) berpengaruh positif terhadap kepuasan kerja karyawan (Y), semakin meningkatkan Lingkungan Kerja (X3) maka akan meningkatkan kepuasan kerja karyawan (Y). Hipotesis (Dugaan) dalam uji t pertama adalah

1. $\mathrm{H}_{0}=$ Lingkungan Kerja (X3) tidak berpengaruh signifikan terhadap Kepuasan Kerja Karyawan (Y)

2. $\mathrm{H}_{1}=$ Lingkungan Kerja (X3) berpengaruh signifikan terhadap Kepuasan Kerja Karyawan (Y)

Hasil dan pengambilan keputusan dalam uji $t$ ketiga: Diperoleh nilai $t_{\text {hitung }}$ sebesar 3,106 $>t_{\text {tabel }} 1,968$ Nilai (Sig) 0,002 <0,05. Maka disimpulkan bahwa $\mathrm{H}_{0}$ ditolak dan $\mathrm{H}_{1}$ diterima, yang berarti Lingkungan Kerja (X3) berpengaruh signifikan terhadap (Y).

\subsubsection{Hasil Analisis Pengaruh Simultan Dengan Uji F}

Bahwa Komunikasi Interpersonal Pimpinan (X1), Motivasi Kerja (X2), Lingkungan Kerja (X3) secara simultan berpengaruh terhadap Kepuasan Kerja Karyawan (Y). Dengan melihat hasil penjabaran, maka dalam uji $\mathrm{F}$ baik dengan membandingkan nila $\mathrm{F}$ hitung dan $F$ tabel, maupun berpedoman dengan nilai signifikansi diperoleh hasil yang sama atau hasil yang konsisten Uji $\mathrm{F}$ digunakan mengetahui variabel (independen) komunikasi interpersonal pimpinan (X1), motivasi kerja (X2), lingkungan kerja (X3) secara bersama-sama (simultan) terhadap variabel dependen kepuasan kerja karyawan. Keputusan uji $\mathrm{F}$ berdasarkan nilai signifikansi, $0,000<0,05$ sesuai dengan dasar pengambilan keputusan dalam uji $\mathrm{F}$ maka dapat disimpulkan pula bahwa Variabel X1, X2, X3 secara simultan berpengaruh terhadap Y. Sedangkan dengan melihat hasil penjabaran tersebut, maka dalam uji $\mathrm{F}$ dengan nilai $\mathrm{F}_{\text {hitung }} 15,021>$ nilai $\mathrm{F}$ tabel 2,644 nilai ( sig)0,000 < 0,05 dapat disimpulkan bahwa ketiga variabel tersebut secara simultan dan konsisten.

\subsubsection{Analisis Regresi Linear Berganda}

Komunikasi interpersonal pimpinan, motivasi kerja dan lingkungan kerja, secara bersama-sama dalam penelitian pengaruhnya terhadap kepuasan kerja cukup rendah Analisis regresi berganda untuk mengetahui ada atau tidaknya pengaruh signifikan dua atau lebih variabel 
bebas (X1, X2, X3, Xn) terhadap variabel terikat( Y). Rumusnya sebagai berikut : $\mathrm{Y}=\mathrm{a}+\mathrm{b} 1 \mathrm{X} 1+\mathrm{b} 2 \mathrm{X} 2+$ b3X3+... + bnXn, analisa Regresi Linear Berganda:

1. Tabel Pengujian $\mathrm{Y}=\mathrm{a}+\mathrm{b} 1 \mathrm{X} 1+\mathrm{b} 2 \mathrm{X} 2+\mathrm{b} 3 \mathrm{X} 3+\ldots+$ bnXn, $\mathrm{Y}=27,699+0,001 \mathrm{X} 1+0.392 \mathrm{X} 2+0.277 \mathrm{X} 3$

2. Penjelasan persamaan tersebut konstanta sebesar 27,699 artinya jika (X1), (X2), (X3) mempunyai nilai 0 maka nilai kepuasan kerja karyawan sebesar 27,699.

3. Koefisien regresi variabel (X1) 0,001 artinya jika (X1) mengalami kenaikan satu satuan maka kepuasan kerja karyawan akan mengalami peningkatan sebesar 0,001 satuan dengan asumsi variabel indenpenden lainnya bernilai tetap.

4. Koefisien regresi variabel (X2) 0,392 artinya jika (X2) mengalami kenaikan satu satuan maka kepuasan kerja karyawan akan mengalami peningkatan sebesar 0,392 satuan dengan asumsi variabel independen lainnya bernilai tetap.

5. Koefisien regresi variabel (X3) 0,277 artinya jika (X3) mengalami kenaikan satu satuan maka kepuasan kerja karyawan akan mengalami peningkatan sebesar 0,277 satuan dengan asumsi variabel independen lainnya bernilai tetap.

Analisis koefisien determinasi (Adjuster R2), nilai $\mathrm{R}$ Square menunjukkan nilai 0,166 atau $16,6 \%$. Hal tersebut bisa diartikan bahwa 16,6 \% kepuasan kerja karyawan di Hotel InterContinental Midplaza Jakarta dapat dijelaskan oleh variabel komunikasi interpersonal pimpinan, motivasi kerja dan lingkungan kerja, sedangkan sisanya 83,4\% dapat dijelaskan oleh variabelvariabel lain diluar variabel komunikasi interpersonal pimpinan, motivasi kerja dan lingkungan kerja. Nilai $R$ Square di penelitian ini cukup rendah sehingga pengaruh variabel (X1), (X2), (X3) terhadap variabel (Y) di Hotel InterContinental ini cukup rendah.

\section{KESIMPULAN}

Komunikasi interpersonal pimpinan, yang terjalin antara atasan dan bawahan bisa meningkatkan kepuasan kerja karyawan hal tersebut untuk menjalin hubungan yang harmonis antara pimpinan dengan karyawan sehingga tujuan perusahaan dapat dicapai dengan optimal. Motivasi yang dilakukan oleh pimpinan dapat memberikan arahan kepada bawahan dalam bekerja dengan baik, memberikan arahan agar karyawan bisa berkarier lebih tinggi, dan memberikan arahan kepada karyawan untuk meningkatkan keterampilan dan pengetahuan. Lingkungan kerja dengan peralatan yang baik dan mudah digunakan akan meningkatkan kepuasan kerja.

\section{SARAN}

Manajemen agar bisa menciptakan hubungan komunikasi interpersonal pimpinan, motivasi kerja, dan lingkungan kerja yang efektif dan terjalin dengan baik agar dapat membantu meningkatkan kepuasan kerja karyawan. Agar peran tersebut dapat terlaksana dengan baik maka perlu dilakukan program komunikasi dengan diadakan focus group discussion (FGD) antara pihak manajemen yang diwakili manajer dengan para karyawan yang dilakukan setiap bulan. Focus group discussion merupakan komunikasi dua arah dalam upaya meningkatkan kepuasan kerja dengan saling mengomunikasikan kebutuhan kedua belah pihak yang dilandasi visi dan misi perusahaan dalam mencapai tujuan perusahaan. Focus group discussion (FGD) harus dijalankan setiap bulan untuk mengetahui seberapa besar pengaruhnya dalam kegiatan perusahaan dengan mengetahui sampai sejauh mana tindak lanjuk dari hasil komunikasi bersama tersebut.

\section{DAFTAR PUSTAKA}

Devito, G. (2016). Human Resource Management Tenth Edition. New Jersey : Prentice Hal.

Edison, E. (2018). Manajemen Sumber Daya Manusia: Strategi dan Perubahan dalam Rangka Meningkatkan Kinerja Pegawai dan Organisasi, . Bandung: ALFABETA.

Ibrahim, M. (2017). Effect of job satisfaction on turnover intention : An empirical investigation on Nigerian Banking Industry.

Luma, M. (2017). Hubungan lingkungan kerja dengan stres kerja guru di SDN Kecamatan Batudaa Kabupaten Gorontalo. Jurnal Manajemen IAIN Menado.

Mangkunegara, A. P. (2017). Manajemen Sumber Daya Manusia. Bandung . Bandung : PT Remaja Rosdakarya Offset

Netto, A. P. (n.d.). Tourism Theory Concepts, Models and Systems. Griffith University.

Nitisemito, A. S. (2014). Manajemen Personalia. Jakarta: Ghalia Indonesia.

Priansa, D. J. (2017). Manajemen Kinerja Kepegawaian dalam Pengelolaan SDM Perusahaan. Pustaka Setia.

Robbins, S. (2015). Psikologi organisasi. Jakarta: Salemba Empat.

Sedarmayanti. (2015). Sumber Daya Manusia dan Produktivitas Kerja. Bandung: Mandar Maju

Sedarmayanti. (2017). Manajemen Sumber Daya Manusia. Reformasi Birokrasi dan Manajemen Pegawai Negeri Sipil. Bandung: PT Refika Aditama.

Siagian, S. P. (2015). Manajemen Sumber Daya Manusia, cetakan 23. Jakarta: bumi aksara.

Sutrisno. (2017). Manajemen Sumber Daya Manusia. Jakarta: Kencana.

Wibowo. (2017). Manajemen Kinerja. Edisi Kelima. Depok: PT. Raja Grafindo Persada. 